Билјана Бујко (САД)

Клинички психолог во приватна пракса

Е-маил: biljana.bujko@gmail.com

\title{
ТРАНСГЕНЕРАЦИСКА ТРАУМА И ЖИЛАВОСТ: „НЕМИСЛЕНОТО ЗНАЕНО - НЕИМЕНУВАНИОТ РАСКИН И ИСЦЕЛУВАЊЕ“
}

Апстракт: Сите форми на опресија, без оглед дали се работи за расизам, геноцид или за ексклузивитет на доминантната група во некој регион или држава, претставуваат системи што имаат влијание врз сите припадници во нивните рамки, влијаат пробивно, длабоко и често несвесно за доминантната група. Трансгенерациската траума е искуство на насилство врз родителите и е пренесено на следните генерации, колонизиран ум од неподносливо и непроцесирано психичко искуство без свесно знаење и интерес тоа да се процесира или да се трансформира. Во последните 20 години се интензивираа истражувањата на оваа тема, поставувајќи го прашањето: на кој начин ги разбираме варијациите на историската траума. Како им помагаме на луѓето да создадат жива врска со „Другиот“ со оглед на промените и поделбите што се сѐ уште живи во современата култура? И најважното прашање: на кој начин ја разбираме и ја олеснуваме врската со длабокото самочувство со цел сите да можат да живеат поавтентичен, поисполнет живот. Авторката објаснува што е тоа траума, како се манифестира трансгенерациската трансмисија, кои се причините и како се развива жилавоста. На крајот е посветено внимание на психологијата на македонскиот етнички идентитет, со посебен акцент на егејскиот егзодус и на ранитеод трансгенерациската траума кај оваа етничка група.

Клучни зборови: траума, трансгенерациска трансмисија, отпорност, македонски идентитет, егејски прогон.

Проучувањата на трансгенерациската трансмисија на траумата започнаа со истражувањето на траумата на холокаустот. Во последниве 20 години истражувањата на сведоштвата за трансгенерациската трансмисија го проширија фокусот на други политички, општествени трауми и геноциди покрај холокаустот. Во последно време се направени многу истражувања за ропството на Афроамериканците, за невидливоста на американските домородци 
во САД, за ерменскиот или камбоџанскиот геноцид, како и за балканските војни во 1990-тите години. Вообичаено, групните трауми вклучуваат војни, геноцид, политички или друг вид прогон.

Зошто постои таа претпоставка во човечката психа дека, за да може една личност или група да се чувствува подобро, мора да постои оцрнување на другите? Насилството врз жените и децата е насилство против човештвото. Сите форми на опресија, без оглед дали се работи за геноцид, расизам или ексклузивитет на одредена доминантна група во рамките на некоја држава или регион, претставуваат системи што влијаат врз сите припадници во нивните рамки, влијаат пробивно, длабоко и често несвесно за доминантната група. На доминантната моќ на една група врз некоја друга група мора да ѝ се пристапи преку образованието, преку дијалог и партнерство меѓу луѓето. За да се избегне насилството, потребно е радикално свртување кон Другиот.

\section{Психоаналитички перспективи во врска со теоријата на траума}

За Фројд, траумата генерално претставува искуство на беспомошност во случај на преоптоварување. Според него, поединецот е заштитен со штит што стои помеѓу внатрешниот стимул и надворешниот стимул. Кога штитот ќе биде скршен или пробиен како резултат на некој шокантен или неподносливо болен настан, извираат многу непроцесирани емоции што предизвикуваат состојба на траума.

Британскиот психоаналитичар Масуд Кан (Masud Khan 1963)

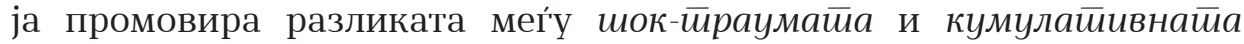
йраума. Шок-траумата е моментална, ненадејна, како средба со смртта. Примери за шок-траума можат да бидат сообраќајна несреќa, силување или загуба на блиска личност. Од друга страна,

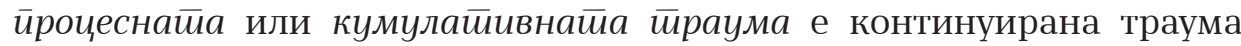
на болка и страдање: на пример, растење со дисфункционален родител или родител алкохоличар, живот во војна, геноцид, прогон итн. Во категоријата кумулативна траума припаѓа и темата што ја обработуваме тука: исйорискайа йраума. Што е тоа историска траума? Историската траума е поврзана со колективното кумулативно емоционално страдање низ генерациите како резултат на големи катаклизмички настани. Овие настани не ги засегаат само поединците туку ја засегаат целата заедница. Процесот што се јавува како резултат на ваквите настани предизвикува лична траума што може да се пренесе на идните генерации. Дури и членовите на семејството што немале директно трауматско искуство може да ги чувствуваат ефектите на настанот со генерации. 


\section{Концепти за траумата}

За да може да се разбере трансгенерациската трансмисија на траумата, потребно е да се разберат нејзините основни концепти. Терминот траума се однесува на важен однос што отишол во погрешен правец кога старателот, општествениот систем или државата не успеваат да обезбедат поддршка за болните чувства на децата или на возрасните. Постојат различни видови траума идентификувани според човечкото искуство. Еден добро познат вид траума за кој е многу пишувано е личната траума што може да се случи како резултат, на пример, на сообраќајна незгода, семејно насилство, војна и воена траума што може да предизвика посттрауматско стресно растројство (ПТСР). Личната траума подразбира дека една личност имала искуство со одреден трауматски настан или синџир на настани што се единствени по својот квалитет. Наспроти ова, интергенерациската траума е присутна низ генерациите, таа е свесна, а пренесувањето ги користи процесите како што се фантазијата и идентификацијата. Таа е организирана во семејниот наратив што се пренесува од една на друга генерација. Раскажаните приказни содржат информации што свесно се пренесуваат на следната генерација. Од друга страна, трансгенерациската трансмисија на траумата се однесува на несвесната ментална содржина што е дисоцијативна, примитивна и неинтегрирана, пренесувана понатаму на следните генерации во таква несвесна форма. Овој вид трансмисија не се симболизира во зборовите или преку приказните. Во суштината на ваквата траума се наоѓаат фрагменти или ментални претстави, парчиња од раскажани или нераскажани приказни. Вообичаено тие се изразуваат преку претставување на непроцесирани емоции, како омраза или завист, припишани културни верувања, гестови, неименувана тага, страв и вознемиреност или периодични соништа и кошмари.

\section{Трансгенерациска траума: причини и трансмисии}

Има голема веројатност трансгенерациската траума да се пренесе кога ќe се појави голема групна траума. Овде сакам да го објаснам концептот на „споделена избрана траума на голема група“ за која зборува Волкан (Volkan 2017) во неговиот опус посветен на траумата. Кога една голема група како македонската споделува загуби, се чувствува беспомошно и е виктимизирана од страна на друга група и кога споделува чувство на омаловажување и други повреди - тоа е клучот со кој се идентификува процесот на трансгенерациска трансмисија на минатите историски настани (Volkan 2002). Некој може да се запраша зошто тогаш се зборува за „избрана“ траума кога групата не избрала да биде виктимизирана. Траумата може 
да биде избрана бидејќи, исто како поединците, и големите групи може да прават несвесни „избори“. Според тоа, терминот „избрана“ се однесува на несвесниот избор. Иако големите групи може да имаат одреден број трауми низ нивните истории, само некои од нив остануваат живи низ вековите. Илјадници и милиони луѓе во големи групи ги споделуваат менталните претстави за одредени трауми. Избраната траума тогаш ја претставува неможноста на претходно трауматизираната генерација да жали за својата загуба, како и неуспехот да се надмине омаловажувањето, срамот или повредата на групната самодоверба нанесени од страна на друга голема група, а тоа вообичаено е соседна група. Тоа значи дека, без оглед на тоа за каква траума се работи, таа не може да зацели без процесот на жалење.

Процесой на жалење или неможноста за жалење кај имигрантите, бегалците и другите жртви на историска траума е главната причина за трансмисија на трансгенерациската траума. Ситуацијата станува уште покомплексна и потрагична во случаите на присилна имиграција (Volkan 2017). Кога луѓето се селат на туѓa локација, тие преживуваат повеќекратни големи загуби: губење на семејството или пријателите, губење на домот или државата, губење на гробовите на предците, губење на јазикот, храната, мирисите, песните, губење на претходниот идентитет и на сопствениот систем за поддршка (Akhtar 1995). „Сите искуства на преселување може да се разгледуваат во однос на способноста на имигрантите или бегалците да жалат и/или да го отфрлат процесот на жалење“ (Volkan 2017: 4).

Фројд го напишал својот познат текст „Жалење и меланхолија“ во 1917 година (Freud 1917). Тој го идентификувал процесот на жалење како искусување болка и сите други негативни чувства поврзани со загубата. Но ако поединецот не поминал низ процесот на жалење по некое трауматско искуство, настапува меланхоличната состојба што трае долго време. Кај многу тешко истрауматизирани поединци, нереализираното жалење може да доведе до недостиг на можноста за симболизирање. Овие неметаболизирани, несимболизирани ментални структури понатаму се пренесуваат на идните генерации. Овие фрагменти може да се разгледуваат како дел од несвесната трансгенерациска трансмисија на омраза, војна и насилство (Volkan 2017; Grand, Salberg 2017a; Grand, Salberg 2017b). Неможноста да се жали и да се биде ранлив на психичка болка може да предизвика континуирано пренесување на насилството и траумата.

Процесот на жалење е многу комплексен и е добро претставен и објаснет во психоаналитичката литература. Овде накратко ќе споменам неколку основни карактеристики на жалењето поврзани со темата за трансгенерациска траума. Таг̈увањейо е важен дел од поширокиот просец на жалење, тоа е минлива, возвишена експресија на болката. Од друга страна, жалењето е целосен процес за чие 
разрешување треба време. Зgравойо жалење е израз на тагување и носталгија што подразбира процесирање и ослободување без да доминира чувството на омраза.

Луѓето што не се во состојба да жалат може да бидат заглавени во меланхолија што подразбира и присуство на чувство на омраза, како и неспособност за жалење и ослободување. Долг̄ойрајнойо жалење е друг вид фиксација што произлегува од одржувањето на специфичниот објект што ја потсетува личноста на загубата, или слушањето на гласовите од минатото поврзани со објектот на загуба (Volkan 2017).

\section{Како се случува трансмисијата на трансгенерациската траума?}

Сметам дека начинот на трансмисија може подобро да се разбере ако се разгледува низ призмата на теоријата на приврзаност (Bowlby 1958; 1982). На кој начин се случува една личност да ги носи во својот ум и тело бројните истории и искуства од семејното наследство на трауми и загуби, заедно со семејната култура и надворешниот свет? Како личностите што преживеале траума им ги пренесуваат овие неискажани фрагменти на своите деца? Верувам дека ваквите истражувања се императив за психоанализата.

Родителите и децата создаваат приврзаност што дозволува длабока несвесна комуникација на стравот и безбедноста, на вознемиреноста и сигурноста, на блискоста и дистанцата, љубовта и омразата, како и на многу други нешта (Bowlby 1958). Честопати сето ова се пренесува преку регистрите на реактивност кон другиот или пак недостигот на реактивност, како и преку активниот процес на регулација на афектите во односот меѓу себството и другоста.

Францускиот психоаналитичар Андре Грин (André Green 1972) опишал една верзија на детско искуство со отсутен родител. Тој вид отсутен родител го нарекол мрйва мајка - некој што е жив, но не е присутен; некогаш бил жив, но сега поради депресија е во состојба на празнотија, со отсуство на вознемиреност или жалење - иразна ūcuхоза (на француски - psychosis blanche, на англиски јазик - blank psychosis, заб. на прев.). Детето се оттргнува од оваа мрйва мајка, додека во исто време се идентификува со неа. Во несвесната психа се инсталира мртвилото или загубата на значењето.

Децата постојано ги набљудуваат гестовите и афектите на своите родители, апсорбирајќи ги нивните свесни или несвесни мисли. Во променливите регистри на реактивност или нереактивност, децата се приспособуваат и се адаптираат на емотивното присуство или отсуство на своите родители, секогаш во потрага по приврзаност (Bowlby 1982). Оваа потрага започнува со раѓањето уште пред 
зборовите, кога има само погледи, загледувања, звуци и допири, како и нивно отсуство. На овој начин се раскажуваат приказните, дури и кога не се зборува, во невербалниот и предвербалниот афективен простор - тивко и гласно, одиграни преку сугестии честопати на имплицитно ниво. За човечкото суштество ова почнува да се случува во нуклеусот на примордијалното Едипово семејство, gвајца роgийели и еgно gейе, што претставува еgногеенерациски моgел што се проширува и ги вклучува влијанијата или нарушената приврзаност низ повеќе генерации (Grand, Salberg 2017a).

На базично ниво, приврзувањето е кислородот на нашиот емоционален живот, кое служи за да се создаде чувство на сигурност и безбедност, дозволувајќи ни да бидеме социјални суштества, учејќи нѐ како да ги регулираме своите емоционални животи. Кога траумата трансгенерациски повторно ќе нѐ посети, начинот на трансмисија може да се најде во рамките на детската емпатична реактивност и врска. Кога постои непроцесирана траума кај родителот, за да може да се приврзе за родителот, детето ќе треба да се вклучи во трауматичната сцена. Преку емпатичното пресликување и преку

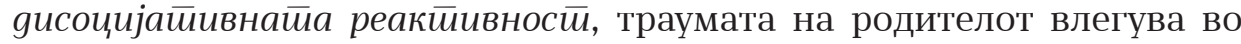
клеточната шминка на детето уште пред тоа да прозборува, односно пред да може да биде раскажана приказната. Има еден прогонувачки квалитет (Harris 2009) на трансгенерациската трансмисија. Духовите на траумата секогаш остануваат таму каде што не се реализирало жалењето. Заклучокот е дека, во недостиг на емоционално витален и целосно присутен родител, детето се приврзува не само со она што е достапно и присутно туку се приврзува и со она што отсуствува -

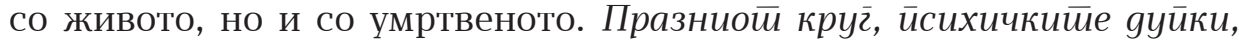

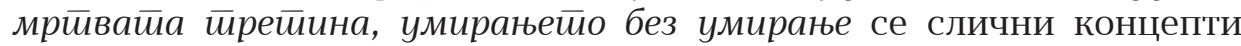
што ги поставиле истражувачите за да го објаснат процесот на дисоцијација, фрагментација и идентификација со старателот (Grand, Salberg, 2017a).

Психоаналитичарот Вамик Волкан (Vamik Volkan 2002; 2017) целата кариера ја поминал во истражување и пишување за големите групни конфликти, за психологијата на имигрантите и бегалците и за трансмисијата на трансгенерациската траума. Тој смета дека трансгенерациската траума се пренесува на детето на два начини:

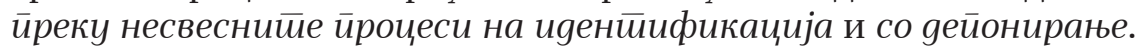

Идентификацискиот процес во раното детство се случува кога детето ги апсорбира и интернализира сликите за родителот, нешто што претходно го објаснив преку теоријата за приврзување. Сепак, постојат други влијанија што децата ги интегрираат од нивната околина, кои учествуваат во создавањето на развојните слики за

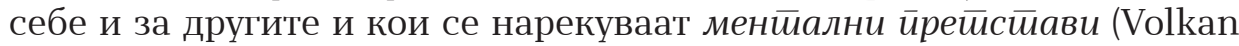
2002). Децата се идентификуваат со мноштво аспекти од значајните личности без оглед дали се тие реални или се фантазија (како на 
пример хероите), па дури и со оние лошите. Тие ги асимилираат мајчинските, татковските, братските/сестринските менторски функции. Идентификацискиот процес, исто така, е под влијание на поголемата група кон која припаѓа семејството на детето, како на пример црквата или општеството. Овие големи групи му пренесуваат на детето религиски, расни, националистички пораки или, пак, пораки на виктимизација и немоќност. Многу рано детето учи да се идентификува со групата преку одредена храна, игра, музика, детски песни, митови, народни приказни, херои и важни настани.

Некои од херојските фигури што придонесуваат кон чувството за македонски идентитет се Крали Марко, Александар Велики и Болен Дојчин (Bujko 2013). Двата најважни македонски митски херои се Болен Дојчин и Крали Марко. Марко е претставен како човек, тој е смртник и е ранлив, но во исто време е претставен и како бесмртен и божествен со нечовечки способности. Неговиот карактер содржи непомирливи спротивности. Во митот за Болен Дојчин херојот Дојчин е тешко болен, но сепак тој наоѓа сила да се бори со непријателот и да ја спаси честа на сестра си. Дојчин го убива Арапинот (непријателот), но, за жал, на крајот самиот умира. Митот ја портретира огромната сила на македонскиот дух, кој може да ги трансформира физички немоќните луѓе преку херојско дело и да ја одржи вербата во храброста (Bujko 2013). На истиот начин историската траума може да учествува во оформувањето на идентитетот на детето преку менталните претстави на споделените перцепции за историските неправди.

Депонирањето е уште еден несвесен начин за пренесување на трансгенерациската траума. Додека процесот на идентификација објаснува како детето ги асимилира аспектите од родителите и од околината во сликата за себеси, депонирањето објаснува како старателите гивнесуваат кајдетето сопствените историски трауматски искуства (Volkan 2002). Со процесот на идентификација детето има активна улога во селекцијата и интеграцијата на менталните претстави, но со депонирањето детето е пасивен реципиент на историјата на друга личност. Депонираните претстави всушност го разјаснуваат начинот на кој се пренесува трансгенерациската траума.

Чест пример за депонирање на ментални претстави е феноменот на заменско gейе. За да илустрирам што значи тоа, ќе дадам еден пример. Кога родителите ќе изгубат дете, менталната слика во нивните глави никогаш не умира. Таа продолжува да постои и кога ќе им се роди ново дете. Оваа слика му се дава на новороденчето и несвесно станува дел од неговата претстава за себеси. Родителот често се поврзува со второто дете како да е тоа првото. Понекогаш на детето му го даваат името од умреното дете, како и неговата колевка или неговите играчки. Новороденото дете нема искуство со мртвото дете, туку родителите всушност ги депонираат овие слики од мртвото 
дете во новороденото и го задолжуваат него да ја одржува жива сликата на мртвото дете (Suistola, Volkan 2017).

Создавањето ваква динамика на заменско дете не е невообичаена за оние што преживеале споделени историски трауми како војна и прогонство. Во такви случаи, сликата што преживеаниот ја носи и ја депонира не е од мртво дете, туку од претрпената колективна болка, од некоја катастрофа или споделена траума. Преживеаниот, кој ги интернализирал сликите за себството и за објектите поврзани со трауматичниот настан, сега несвесно ги пренесува понатаму, ги депонира овие слики на своето поколение. Овие болни слики се претстави на ранетото себство, на сопствената жртва и на виктимизацијата на другиот, на омразата кон престапникот и на сите други болни емоции што доаѓаат заедно со овие ментални претстави.

Она што ги одржува овие ситуации трагични и трауматични и што помага да се пренесе траумата понатаму е неможноста на старателот за жалење за оригиналниот трагичен настан и за загубите. Немисленойо знаено (The unthought known), терминот што го употребува Болас (Bollas 1989), односно внатрешното знаење, е проектирано во несвесното. Понекогаш тоа се манифестира како чување тајни (меланхолија), понекогаш како држење до објектите и гласовите од минатото (постојано жалење) и понекогаш се појавува во соништата.

\section{Дали чувањето тајни е манифестација на трансгенерациска траума?}

Чувањето тајни го создава немисленойо знаено кај следните генерации. Тајните може тивко да трауматизираат и да предизвикаат следната генерација да го почувствува трауматскиот ефект на различни начини. Не постои такво нешто како тишина, во смисла на тишина поврзана со чувањето тајни. Пренесувањето на тајните од една на друга генерација може да биде суптилно затскриено или очигледно. Тие може тивко да се пренесат. Штом еднаш се пренесат, тајните дури можат да создадат животни теми што ја претставуваат суштината на нечиј идентитет. Современиот психоаналитичар Фонаги (Fonagy, Target 1998; Allen, Fonagy, Bateman 2008) смета дека постои имплицитно „знаење“ за тајните на блиските, и тоа има врска со процесот на менйализација (Fonagy, Target 1998).

Ментализацијата го претставува капацитетот на поединецот да ги прочита мислите на друга личност - во однос на намерите и емоциите; и капацитетот да разбере на кој начин тој е доживеан од друга личност или од група луѓе. Ментализацијата вообичаено се јавува на несвесен или имплицитен начин. На пример, кога родителот 
не може да инкорпорира или да размислува за одредена реалност и во тој случај не може да му го овозможи на детето тоа преку игра што вклучува застрашувачки идеи, според Фонаги, тука се работи

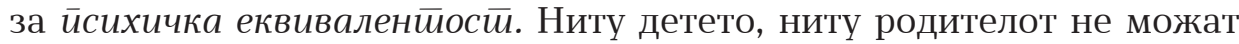
да ја „метаболизираат“ мислата, и така „немислените“ мисли се пренесуваат од една на друга генерација.

\section{Колку генерации можат да бидат вклучени во трансгенерациската трансмисија?}

Зборот „трансгенерациска“ подразбира вклучување на неколку генерации во процесот на трансмисија на траумата. Истражувањата покажуваат дека три или повеќе генерации можат да бидат вклучени во трансмисијата, а понекогаш дури и до седум. Фаимберг (Faimberg

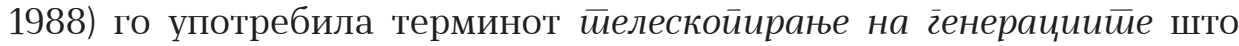
значи дека минатото на родителот и сегашната реалност на детето се измешани, стануваат замаглени како резултат на родителското искористување на детето - феноменот на депонирање. Можеби треба половина век за да се процесира војна и можеби уште подолг гестациски период на тишина.

\section{Епигенетика}

Епигенетиката е област што брзо се развива и се занимава со „двонасочната размена меѓу наследството и околината“ или со воспитувањето наспроти природата. Оваа област нуди објаснувања за начините на кои факторите на околината и историското време може да влијаат врз генетските експресии и можните наследни аспекти на овие експресии. На пример, последните истражувања на невронауката укажуваат дека епигенетиката може да објасни некои од наодите за трансгенерациска трансмисија на стрес, според истражувањата на стаорците што ги нуди литературата. Идентификувана е врската меѓу неорганизираните стратегии на приврзување и повишените нивоа на кортизол на стресорите. Покрај ова, студиите за човечкото поврзување веќе ја документирале интергенерациската трансмисија на стратегиите за приврзување во три генерации. Во сумираните откритија за ефектите на околината врз епигенетиката, Колер (Kohler 2012) вели:

„Некои ейигеенейски 'маркери', о овносно

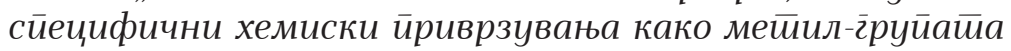

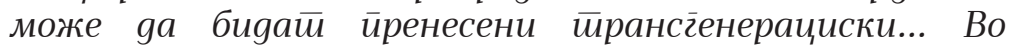

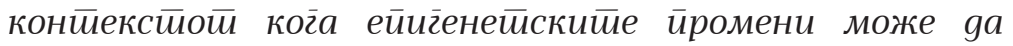




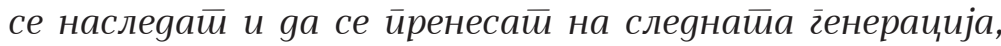

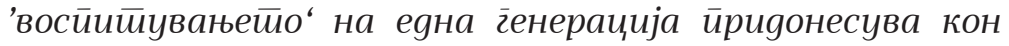

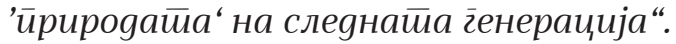

На овој начин, трансгенерациската трансмисија може да се концептуализира на различни нелинеарни начини: трансмисиите се секогаш мултигенерациски и целосно стимулирани од контекстот (историски и личен) и тие се вгнездени во умот и во телото. Ниту една теорија сама по себе не може да го објасни ова, и затоа мора да се бараат многу извори и да се земат предвид различни светогледи за да се разбере комплексноста на поединечните и на групните искуства. На пример во моето истражување за македонската комплексна психа, јас истражував во социополитичката област, во антропологијата, историјата и психологијата (Bujko 2013).

\section{Жилавост}

Како може траумата да се трансформира во позитивно искуство? Што се случува трансгенерациски за да се распространи или да се трансформира нешто што некогаш било ужасно искуство? Жилавоста во психоаналитичката литература се дефинира како капацитет за да се метаболизира трауматскиот ефект, способност за надминување на сериозни тешкотии. Литературата едвај почнува да вклучува експлицитен поглед на силата што се пренесува на следните генерации и на долгорочните капацитети за љубов, поврзаност, посветеност и активизам што често ги наоѓаме кај следните генерации. За да може насилните репетиции да се трансформираат во закрепнување, треба да се претстават овие капацитети.

Приврзувањето се разликува од траумата во смисла на тоа што е посеопфатно и истовремено поексплицитно во своите предвидувања на резултатите. Приврзувањето се случува единствено во детството, а траумата може да се случи и во возрасниот период. Ова го објаснува факторот жилавост. Жилавоста е поединечно дефинирана врз база на природата на приврзувањето. Ако детето е безбедно приврзано и има доволно добро искуство со родителите, кога ќе биде соочено со тешка траума, тоа ќе манифестира жилавост.

Исто така постои уште една компонента за йромена на улог̄uйе што се случува во траумата на односите и што влијае врз развојот на жилавоста. Децата на трауматизирани родители, кои се некогаш живи, а некогаш умртвени и отуѓени, немаат друг начин освен да научат како да бидат реактивни на состојбата на нивните родители и да се обидуваат да ги регулираат нивните афекти и она што е скршено внатре во нив. На овој начин детето може да развие еден вид жилавост, бидејќи со промена на улогите детето треба да порасне побрзо и да биде внимателно во смисла на подобро менаџирање со 
чувствата. Во психологијата се користи терминот ӣаренӣификација за ваквите деца. Пренесувањето на силата, креативноста и жилавоста се случува заедно со пренесувањето на раните.

\section{Македонската психа}

Како ја разбираме македонската психа, и што е тоа што ја прави оваа група единствена? Јас ги истражував космогониските обреди при раѓање и умирање и заклучив дека не само што тие придонеле во формирањето на културниот, националниот и личниот идентитет туку тие се и симболичка експресија како на несвесните елементи на трансгенерациската трансмисија така и на жилавоста.

Како што споменав претходно, јас добив некои нарации за групната траума и страдање од моите информатори, кои претставуваат усна традиција, но голем дел од наративите во македонската култура се пренесуваат низ генерациите и преку народната литература. Во продолжение ќе дадам пример за некои трауми кај Македонците.

Приказните за поразените херои во македонската народна литература се фасцинантни. Во македонската историја Крали Марко е татковска фигура за луѓето, односно повеќе е ослабен татко што ја изгубил моќта да ги заштити своите луѓе. Тој бил заглавен меѓу неговата желба да им помогне на своите луѓе и неговото чувство на беспомошност поради реалното присуство на непријателот (Вражиновски 1999). Овој парадокс е темата на неговото трагично постоење.

Слично трагично постоење е карактеристично и за Болен Дојчин, уште еден поразен херој во историјата. Националниот лик на Крали Марко ја претставува длабоката психолошка динамика на целата македонска група. Неговиот пораз во борбата со големата сила бил трагичен, но неговата лојалност и грижа го претставува нескршливиот групен дух на луѓето (Вражиновски 1999). Овие елементи можат да се најдат во македонскиот основен идентитет.

\section{Македонскиот основен идентитет (или комплекс)}

Што е тоа основен идентитет? Кога менталната претстава на масовна колективна траума станува етничко или национално обележје, еден вид маркер, таа мора да биде вткаена како дел од

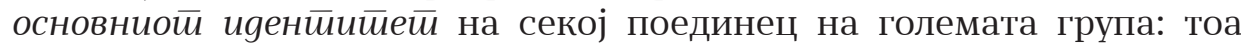

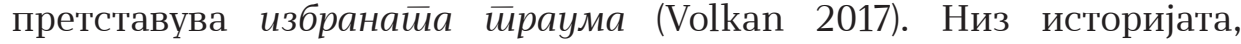
утврдено е дека Македонците се бореле за признавање на нивниот идентитет. Во моите претходни истражувања се занимавав со 
анализирање на комплексноста на македонската психа (Bujko 2013). Дојдов до заклучок дека македонската психа содржи збир од свесни и несвесни елементи што формираат одреден комплекс. Овој комплекс има биполарна природа, што значи дека содржи и позитивни и негативни обрасци на однесување што претходно биле трансгенерациски интегрирани во психата. Стравот од уништување е фундаменталниот страв и е суштинскиот елемент проектиран во македонската психа.

\section{Стравот од уништување и биполарноста на комплексот}

Какорезултатнамногувековнитеопресииитрансгенерациската траума, македонската групна психа станува фрагментирана. Во отсуство на силна татковска фигура, Македонците биле изложени на суштински позитивни машки татковски аспекти (Крали Марко, кој е симбол на името и на идентитетот), така што во групната психа се интегрирале ослабени и поразени ментални претстави што довеле до развивање на културен комплекс или основен идентитет. Темните сили, како на пример силата и моќта, биле проектирани на „другиот“, на непријателот - како Црна Арапина или Арапот што го претставува непријателот на народот. Македонците останале свесни за сите позитивни мајчински аспекти како раздвоени од негативните заслабени татковски аспекти. Ова ја објаснува биполарната природа на комплексот и се активира низ следниве процеси во македонската психа: заканата од повторливата траума и опасните ситуации го активираат одбранбениот самозаштитнички систем, кој испраќа дополнителни пораки дека, доколку оваа група го изрази своето незадоволство агресивно и отворено, тогаш тоа може да води до уништување на групата. Тензичниот страв од агресорот, во минатото османлискиот непријател, а денеска Грција, има автентична експресија; тој бара безбеден пат за да се ослободи и избегнува да предизвикува лоша слика или да провоцира бес во светот што може да поттикне поголема опресија, прогон и уништување, и затоа останува мал и инфериорен. Тензичниот страв го дестабилизира самопочитувањето на македонската група. Дел од стравот од уништување е илустриран со изреката: „Македонија нема да постои, повторно ќе биде поделена еден ден“. Ова е честа изрека, која го интензивира повторливото трансгенерациско заканувачко чувство за губење на идентитетот и која понатаму се пренесува низ генерациите. 


\section{Примери за трансгенерациска трансмисија на траума во македонската психа}

Стана ми ја раскажуваше нејзината омилена приказна од детството, која била пренесувана низ генерациите во нејзиното семејство, а која содржи несвесни елементи што постепено стануваат свесни низ нарацијата:

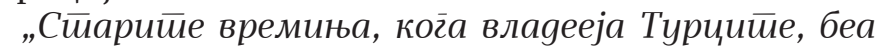

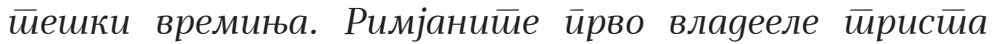

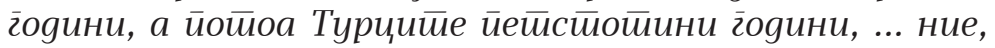

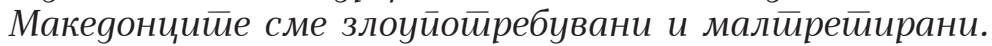
... Ушйе оg Александар Макеgонски, ние сме йроколнайи йораgи нег̄o ... бияејќи мајка му сакала gа г̃о ойруе.

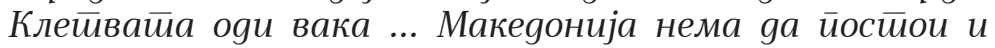

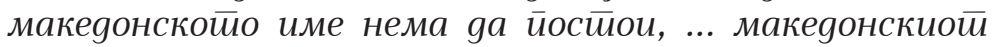
нароg йреба gа бияе сойрен и унишйен, йој йреба gа

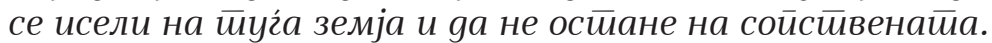

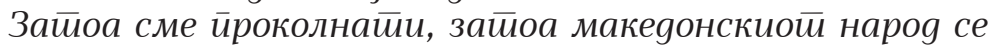

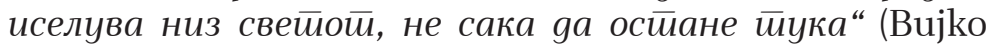
2013: 187).

Неколку теми во убедувањето на Стана укажуваат на важноста на македонскиот идентитет. Во семејството на Александар Велики, антички Македонец, семејното предавство предизвикало клетва што влијаела на иднината на Македонија и Македонците. Античката клетва на Александар Велики, антички македонски херој чиј млад живот завршил трагично, таа ја поврзува со современите проблеми со Грција, која одбива да ја признае Македонија. Тој страв дека Македонија нема да постои или ќе остане безимена е жив во психата на македонскиот народ. Живее активно во секоја личност, како што покажува приказната на Стана. Сепак, преку трансгенерациската тензија, Стана станала жилава, обидувајќи се да го извлече најдоброто од нејзиниот живот (Bujko 2013).

\section{Примери за жилавост}

Тажачките на погребите во Македонија имаат медијаторска функција во стимулацијата на тажењето и жалењето. Еве една изјава на еден од учесниците во моето истражување:

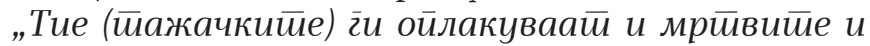

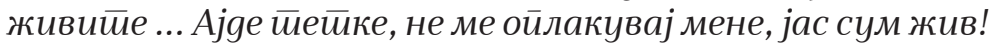

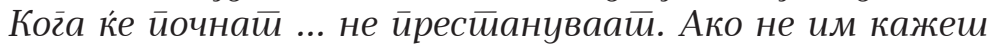

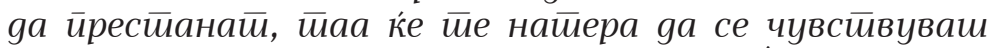

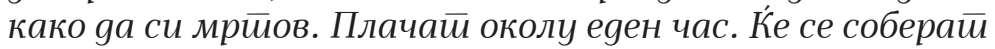




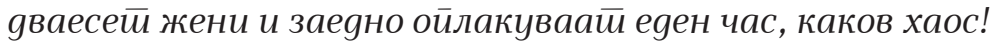

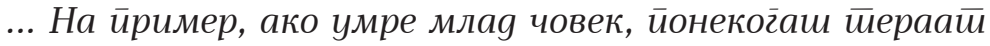
неколку часа, а ког̄а ќе се врайиме дома, лицайа ни се йойечени, ожалосииени и иллачлви“(Bujko 2013: 10).

Која е функцијата на тажачките? Тие го зајакнуваат колективниот процес на здраво жалење. Тогаш жалењето се фокусира не само на мртвите, туку жалењето за многу други загуби се процесира преку смртта на една личност. Тоа ја овозможува исцелувачката функција, кога вратите на плачот се отвораат, се оплакуваат мноштво сеќавања на стари загуби. Ако некој не може да ја толерира таа колективна тага или избегнува погреби, таа личност се опира на жалењето и може да заглави во меланхолична состојба, така што е можно да стане носител на несвесното од трансгенерациската трансмисија на траума. Таа личност се плаши од тагување бидејќи болката може да биде преголема и може никогаш да не престане.

Македонците низ вековите многу добро интуитивно знаеле како да се справат со траумата. Тие ги имале своите обреди.

Обредите при раѓање и смрт и верувањата не само што им нудат на Македонците религиски, културни и космогониски значења за човековото постоење туку тие нудат и безбеден простор за комплексно психолошко исцелување, кое главно вклучува идентификација, процесирање и ослободување на афектот. Паганските елементи во обредите им дозволуваат на луѓето да користат мноштво симболични претстави, често продукти на природата за да ги означат неискажливите несвесни делови од психата, и во тој процес голем дел од непроцесираниот афект е означен и ослободен. Светиот процес на обредите и поврзаноста со природата често предизвикуваат соматска, катарзична и инстинктивна регулација на афектот наместо само когнитивна. Жилавоста што се гради низ времето е зајакната од безбедноста што ја нудат обредите и народните верувања во врска со одредени магиски моќи на даровите од природата.

Обредите при раѓање подразбираат перинатална општествена транзиција, која овозможува културна поддршка од 40 дена по породувањето. Тие имаат две функции: а) да го дочекаат бебето, б) да ѝ помогнат на мајката да се приспособи на нејзината нова мајчинска улога. Тие може да ја редуцираат можноста за постпородилна депресија. Женското друштво е суштинско во ова време бидејќи тоа го нормализира, поддржува и го слави искуството на новата мајка. Така, мајката се подучува како да се поврзе со своето дете и да ја зајакне безбедната приврзаност, која е најважниот елемент за жилавоста.

Посмртните обреди во Македонија имаат две главни функции: а) влез во натприродниот магиски простор во кој живите ги слават мртвите, б) да го започнат процесот на жалење во кој се вклучени живите, не само најблиските туку и пошироката заедница. Втората 
функција на обредите што ги вклучуваат живите во жалењето за мртвите е важна за процесот на прифаќање и реанимирање на живите. Процесот на жалење е комплексен процес, кој има потреба од идентификација, експресија и валидација на негативните чувства. Учесниците не само што се во допир со нивните чувства за загуба туку и голем дел од нивната поранешна траума е процесирана до одреден степен додека сведочат на колективното жалење, кое често ги вклучува тажачките.

\section{Егејскиот егзодус. Како да се исцелат раните од трансгенерациската траума?}

За време на егејскиот егзодус, личната историја била уништена, субјективноста и посебноста биле избришани, и човечките субјекти станале објекти, безимени и непрепознатливи. Нивните имиња биле променети, биле присилени да учат грчки јазик и им било забранувано да го зборуваат својот јазик преку брутални методи употребувани од страна на власта. Луѓето што биле избркани од нивните домови и кои биле во егзил низ Европа, САД, Канада и Австралија сѐ уште живеат со овие „духови од детството“, кои се всушност духови од минатото.

Во најновата историја со егејскиот егзодус биле разделени семејства, а изгубените и отуѓени деца биле раштркани низ светот. На кој начин се зголемува беспомошноста, срамот, понижувањето и виктимизацијата на овие семејства? Многумина од преживеаните на овој трагичен процес се собираат за да ги раскажат своите приказни во служба на исцелувањето, но многумина во себе носат несвесни фрагменти од таа траума, кои ги пренесуваат на идните генерации. Останува индивидуална, но и колективна задача на македонското општество да стане посвесно за овие елементи бидејќи оваа траума нѐ засега сите и оваа траума е нашиот основен идентитет.

Постојат бројни начини како да му се помогне на несвесното да стане појасно. На пример, во рамките на семејниот систем што обрнува внимание на приказните на постарите, кога семејството заедно ги слуша наративите и жалењата, може да се создаде интимност и исцелување. Да се биде реактивен на несвесните пораки, на неискажаните вистини и тајни, визуелни експресии, како и обрасци што веќе немаат улога, може да помогне за да се разјасни трауматичното чувство. Возрасните мора да бидат свесни за начинот на кој зборуваат со своите деца, тие треба да внимаваат на сублиминалните пораки што им ги пренесуваат ним. Исто така, барањето на колективна поддршка надвор од семејната група, како мүзички собири, игри, славење на раѓање, свадби и тажење на погреби, помага за да се зближат луѓето во едно колективно емоционално 
искуство, особено поради тоа што се работи за космогониски обреди што го засилуваат жалењето и жилавоста.

На пошироко општествено ниво, вклучувањето преку мирен активизам за општествена правда овозможува поединечно задоволство, како и вредни искуства што создаваат значење. За потешки или хронични презентации и проблеми, неопходно е да се побара професионална психијатриска или психолошка помош. Во заедницата од професионалци за ментално здравје фокусот треба да биде на мониторирање на меланхоличните состојби, подигнувајќи ја свесноста за потребата од помош преку организирање на психоедукација за трансгенерациската траума, доброволна работа или овозможување соодветни прегледи за психотерапија и други сервиси за социјална грижа. Многу е важно за семејствата на преживеаните од трансгенерациска траума да ја посетат старата земја, местата каде што се случила траумата, како и спомениците преку кои се сеќаваме на настаните. Зборувањето со луѓе што го посведочиле настанот или со оние што можат да раскажуваат такви приказни ќе им помогне да ја откријат вистината за тоа што се случило во минатото. Откривањето на вистината ќе им помогне на идните генерации да го прифатат она што се случило во минатото, да жалат и да ги реинтегрираат овие искуства како дел од нивниот идентитет.

\section{Превенција и професионална помош. Моќта на сведоштвото и интервенција во сведоштвата}

За време на процесот на интервенција на сведоштвата, мора да постои некој настан или искуство, понекогаш долготрајно, но нераскажано, кое често не е свесно формулирано. Оваа информација така го привлекува вниманието на оној што слуша, кој е заинтересиран за да ја прими, и на тој начин таа станува изречена или снимена. Сведоштвото, според тоа, е пренесување на информации што ја задоволува постојаната потреба да се пренесе информација во присуство на надворешна подготвеност таа да се прими. Кога ќе заврши трансмисијата на приказната, преживеаниот повеќе не се чувствува осамен под притисок на тајната што превенира тој да стане жртва на нејзиното влијание. Смислата сега се состои од интерни сензации и афекти, организирани во рамката на хронолошки наратив. Преку искажувањето тие сега се запаметени, пренесени понатаму и може да бидат заборавени. Тие што ја преживеале траумата мора да почувствуваат дека има безбеден простор и внимание за нивната приказна. За нив е многу разочарувачки ако нема публика што ќе ја посведочи нивната трагедија; тие може лесно да се затворат, да станат депресивни и да ја потиснат целата траума во себе, која потоа ќе биде несвесно пренесувана. 
Овој процес може успешно да напредува преку терапија, но сепак, ако сте дете со капацитет да го слушате својот родител, се отвора трета димензија за двајцата, и на овој начин се забележуваат трансгенерациските ефекти: детето мора да го забележи својот афект за деталите во приказната, да го разграничи она што е негово паметење на приказната, а што е реалноста на приказната за нејзиниот наратор. Често е тешко за децата да ги замислат своите родители како имаат потреба да бидат деца и некој да се грижи за нив кога се случува траумата. Спојувањето на празнините во приказната заедно е еден од начините за заедничко преживување со моќен ефект.

\section{Психотерапија}

Една од целите на психоаналитичката психотерапија е да го направи свесно она што е несвесно, да ја прошири сферата на егото и да му помогне на пациентот да стане посвесен за неговите минати трауматични искуства, дефинирајќи ја и диференцирајќи ја неговата мината и сегашна реалност и изнаоѓајќи начини за поврзување со другите. Неопходни се клинички речник и етичка рамка за да се справи со траумата, како и еден вид релациона љубопитност, која ќе го зајакне неговото сведоштво. Културната компетентност на терапевтот сама по себе не го отвора дијалогот. Неговото познавање на историјата и внимателниот преглед на социополитичката и културната историја на семејството на клиентот во минатите генерации се неопходни за да се третира трансгенерациската трансмисија. Знаењето за историјата е неопходно за да може да знае кои прашања да ги постави - тоа е клучниот фактор за компетентност.

Паметењето, повторувањето и преживувањето, кои се вклучени во психоаналитичката патека, не само што можат да ја воспостават емоционалната рамнотежа, туку исто така, преку прегледувањето на невронската мапа што ги поврзува мислите и емоциите, може да се намали биолошката штета. Навремениот професионален третман за трансгенерациската траума на приврзување, кога трауматизираниот пациент наоѓ д дабоко емпатичен сведок во својот терапевт, може да му дозволи на родителот/пациентот постепено да излезе од отуѓеноста и да се оспособи за чувството на болка, терор и тага за прв пат. Покрај ова, терапевтот може да ја користи терапијата на жилавост, која е вид терапија што помага да се идентификуваат „духовите од детството“ како трауматски слики и да се пронајдат „ангелите во детството“, заштитнички фактори што овозможуваат извор на интернализирана поддршка, кои дополнително ја зацврстуваат жилавоста. Исто така, групниот процес и групната терапија често им помага на имигрантите, бегалците и жртвите на траума да почувствуваат поддршка, да 
се почувствуваат помалку изолирани и да го зајакнат чувството за припадност.

\section{Заклучок}

Кога личноста, свесно или несвесно, се чувствува како да е предадена од родителот, лидерот, идеологијата, верата или од партнерот, таа се чувствува толку понижено што мора да верува или што има потреба да верува. Тогаш жртвата често пати носи суицидни чувства на срам, кои всушност би требало да ги чувствува другата страна, онаа на предавниците. Срамот секогаш го опструира или барем го комплицира животот и има потреба од паметење и жалење.

Психолошката способност да се познава сопствениот идентитет подразбира да се земат предвид историските факти, артефакти, митови и начини на постоење во светот, како и да се прифати минатото и да се жали по загубите, што ѝ овозможува на личноста да го прифати сопствениот идентитет. Ова е фундаментален фактор во градењето на македонската самодоверба. Само тогаш оваа група ќе може да преговара за своите потреби со светот, за своето присуство, потенцијал и придонес.

Без залажување и срам, секој од нас има потреба да се позанимава со прашањето како може минатото што прогонува да биде меморирано на корисен начин. За да резимирам, јас би сакала да ги изнесам следните препораки за исцелување на раните од трансгенерациската траума: раскажување на приказната на некој што може навистина да слуша, жалење за минатото и за загубите, градење споменици и сеќавања, собирање на музички настани и обреди. Да запаметиме дека вистинскиот споменик е дијалогот со Другиот.

\section{Литература}

Akhtar, S. 1995. “A Third Individuation: Immigration, Identity, And The Psychoanalytic Process”, Journal Of The American Psychoanalytic Association, 431051-1084.

Allen, J. G., Fonagy, P., \& Bateman, A. 2008. Mentalizing in Clinical Practice. Washington, DC: American Psychiatric Pub.

Allen, J. G., Fonagy, P., \& Bateman, A. 2008. Mentalizing in Clinical Practice. Washington, DC: American Psychiatric Pub.

Bollas, C. 1989. The Shadow of the Object: Psychoanalysis of the Unthought Known. New York: Columbia Univ. Press. 
Bowlby, J. 1958. "The nature of the child's tie to his mother", Int. J. Psycho-Anal. 39: 350-373.

Bowlby, J. 1982. Attachment. New York: Basic Books.

Bujko, B. 2013. Identifying Cultural Complex by Examining the Myth and Rituals About Birth and Dying in the Macedonian Culture and their Influence on Shaping the Ethnic/National Identity (Unpublished Doctoral Dissertation) Pacifica Graduate Institute, Carpinteria, CA.

Faimberg, H. 1988. "The telescoping of generations: Genealogy of certain identifications", Contemporary Psychoanalysis 24: 99-117.

Fonagy, P. \& Target, M. (1998). "Mentalization and the changing aims of child psychoanalysis”, Psychoanal. Dial. 8: 87-114.

Freud, S. 1917. Mourning and Melancholia. The Standard Edition of the Complete Psychological Works of Sigimund Freud, Volume XIV (1914-1916): On the History of the Psycho-Analytic Movement, Papers on Metapsychology and Other Works, 237-258.

Grand, S. \& Salberg, J. 2017a. Trans-Generational Trauma and the Other: Dialogue across history and difference. New York: Routledge.

Grand, S. \& Salberg, J. 2017b. Wounds of History: Repair and Resilience in the Trans-Generational Transmission of Trauma, New York: Routledge.

Green, A. 1972. The dead mother. In On Private Maddness, London: Rebus Press

Harris, A. 2009. You Must Remember This. Psychoanalytic Dialogues 19: 2-21.

Khan, M.R. 1963. The Concept of Cumulative Trauma. Psychoanal. St. Child, 18: 286-306.

Kohler, B. 2012. Relational psychosis psychotherapy: a neuropsychoanalytic model. Paper presented at the meeting of the American Association of Psychoanalysis, Physicians, Washington, DC.

Ornstein, A. 2003. "Survival and Recovery: Psychoanalytic Reflections", Chapter 5, Progress in Self Psychology, 19: 85-105.

Suistola, J. \& Volkan, V. 2017. Religious Knives: Historical and Psychological Dimensions of Internantional Terrorism, Durham, NC: Pitchstone.

Volkan, V. 2017. Immigrants and Refugees: Trauma, Perennial Mourning, Prejudice, and Border Psychology. London: Karnac.

Volkan, V. 2002. The Third Reich in the Unconscious. New York: Brunner-Routledge. 
Vražinovski, T. 1999. Narodna tradicija: Religija, kultura. Skopje: Matica makedonska. 